\title{
Neurological Complications of Mycoplasma pneumoniae Infection in Children
}

\author{
Çocuklarda Mycoplasma pneumoniae Enfeksiyonunun \\ Nörolojik Komplikasyonları
}

\author{
Zeynep Gökçe Gayretli Aydın', Elif Acar Arslan² \\ ${ }^{\prime}$ Department of Pediatric Infectious Diseases, Karadeniz Technical University School of Medicine, Farabi Hospital, Trabzon, Turkey \\ 2 Department of Pediatric Neurology, Karadeniz Technical University School of Medicine, Farabi Hospital, Trabzon, Turkey
}

Cite this article as: Gayretli Aydın ZG, Acar Arslan E. Neurological complications of Mycoplasma pneumoniae infection in children. J Pediatr Inf 2019;13(2):e67-e73

\begin{abstract}
Objective: One of the most common extra pulmonary diseases of Mycoplasma pneumoniae is neurologic disorders. It may cause neurological diseases such as meningitis, meningoencephalitis, cerebellitis, polyneuropathy, acute disseminated encephalomyelitis (ADEM), stroke, transverse myelitis, Guillain-Barre syndrome, myasthenia gravis (MG), peripheral neuropathy. Although the pathogenesis of $M$. pneumoniae-associated neurological diseases cannot be fully elucidated, it is thought to be mediated by immune mediated or direct invasion of the microorganism. In this study, nine children with M. pneumoniae associated different neurological involvement were presented.
\end{abstract}

Material and Methods: Patients with serum M. pneumoniae immunoglobulin M (lgM) positive were retrospectively reviewed. Demographic, clinic, laboratory and imaging results of patients with central nervous system involvement were evaluated.

Results: Neurological disorders was detected in 12 of 107 patients with serum M. pneumoniae lgM positive.Three patients were excluded due to pre-existing neurological disorders. Four of the patients with neurological involvement were female and five were male. Age of the patients was between 3-12 years. Four cases were aseptic meningitis, one case meningoencephalitis, one case ADEM, one case cerebellitis, one case cerebellar ataxia, one case MG.

Conclusion: Although M. pneumoniae is known as the main respiratory pathogen, it also causes a variety of neurological disorders. M. pneumoniae should be investigated in patients with neurological involvement whether or not there are signs and symptoms of the respiratory system.

Keywords: Mycoplasma pneumoniae, children, neurologic omplications öz

Giriş: Mycoplasma pneumoniae'nın en sık neden olduğu ekstrapulmoner hastalıklardan biri nörolojik hastalıklardır. Menenjit, meningoensefalit, serebellit, polinöropati, akut disemine ensefalomiyelit (ADEM), inme, transvers miyelit, Guillain-Barre sendromu, myastenia gravis (MG), periferal nöropati gibi nörolojik hastalıklara neden olabilir. M. pneumoniae ilişkili nörolojik hastalıkların patogenezi tam olarak aydınlatılamamakla birlikte, immün aracılı veya mikroorganizmanın direkt invazyonu sonucu ortaya çıktığı düşünülmektedir. Bu çalışmada M. pneumoniae ilişkili farklı nörolojik tutulumu olan dokuz çocuk hasta sunuldu.

Gereç ve Yöntemler: Serum M. pneumoniae immünglobulin M (IgM) pozitifliği olan hastalar geriye dönük olarak tarandı. Santral sinir sistemi tutulumu olan hastaların demografik özellikleri, klinik, laboratuvar ve görüntüleme sonuçları değerlendirildi.

Bulgular: Serumda M. pneumoniae IgM pozitifliği saptananan 107 hastanın 12'sinde nörolojik tutulum tespit edildi. Önceden var olan, nörolojik hastalıkları nedeni ile üç hasta çalışma dışı bırakıldı. Nörolojik tutulumu olan olguların dördü kız, beşi erkek olup, yaşları 3-12 yaş arasında idi. Dört olgu aseptik menenjit, bir olgu meningoensefalit, bir olgu ADEM, bir olgu serebellit, bir olgu serebellar ataksi, bir olgu MG tanısı aldı.

Sonuç: M. pneumoniae başlıca solunum sistemi patojeni olarak bilinmesine rağmen çok çeşitli nörolojik hastalıklara da neden olmaktadır. Solunum sistemi semptom ve bulguları olsun olmasın nörolojik tutulumla karşımıza çıkan hastalarda M. pneumoniae etken olarak araştırıımalıdır.

Anahtar Kelimeler: Mycoplasma pneumoniae, çocuk, ekstrapulmoner tutulum

\footnotetext{
Yazışma Adresi / Correspondence Address

Zeynep Gökçe Gayretli Aydın

Karadeniz Teknik Üniversitesi Tıp Fakültesi Farabi Hastanesi,

Çocuk Enfeksiyon Hastalıkları Bilim Dalı,

Trabzon-Türkiye

E-mail: zggayretli@gmail.com
}

Received: 03.01.2019

Accepted: 20.04 .2019
๑Copyright 2019 by Pediatric Infectious Diseases and Immunization Society. Available online at www.cocukenfeksiyon.org 


\section{Introduction}

Mycoplasma pneumoniae is an atypical bacterium without a cell wall which causes primary respiratory infections as pharyngitis, pneumonia, and tracheobronchitis. It infects the respiratory tract by being transmitted through droplet from person to person and by adhering to epithelia cells with filamentous structures. Apart from respiratory tract infections, M. pneumoniae leads to various extrapulmonary diseases at a rate of $25 \%$ including hemolytic anemia, polyarthritis, erythema multiforme, hepatic, cardiac, and neurologic diseases (1). One of the most commonly encountered extrapulmonary diseases is neurologic (2). Neurological involvements such as meningitis, meningoencephalitis, cerebellitis, polyneuropathy, acute disseminated encephalomyelitis (ADEM), stroke, transverse myelitis, Guillain-Barre syndrome, myasthenia gravis (MG), and peripheral neuropathy have been reported at a rate of $1 / 1000$ among all $M$. pneumoniae infections $(1,3)$. In most of these cases, M. pneumoniae is diagnosed according to serologic test results. Although the pathogenesis of $M$. pneumoniae-associated neurological diseases cannot be fully elucidated, it is thought to emerge by immune mediated or direct invasion of the microorganism (1). In this study, nine children with different $M$. pneumoniae-associated neurological involvements were presented.

\section{Materials and Methods}

Patients with $M$. pneumoniae immunoglobulin $M$ (IgM) positivity followed in Farabi Hospital of Karadeniz Technical University Medical School between July 2015 and August 2018 were retrospectively reviewed. M. pneumoniae serology was checked in serum and in convalescence serum if possible in the acute phase using the M. pneumoniae specific IgM and immunglobulin $\mathrm{G}$ (lgG) enzyme immune assay method. An above fourfold increase in the lgG titer in serums taken at the acute phase and in the convalescence period 7 days to 3 weeks after the onset of the disease was accepted diagnostic for M. pneumoniae infection. M. pneumoniae DNA was performed with real time polymerase chain reaction (PCR) in the swab sample taken from the respiratory tract. The cases were grouped as prolonged coughed, pneumonia, parapneumonic effusion, arthritis, hemolytic anemia, and central nervous system (CNS) involvements. Patients with CNS involvement were assessed in company with demographic, clinical, laboratory, and imaging results. Presence of enterovirus, parechovirus, herpes simplex-1, herpes simplex- 2 and varicella zoster virus $(V Z V)$ in the cerebrospinal fluid samples were performed on TR-PCR (BD MAX System, the USA) using multiplex real time PCR (RT-PCR) kits (BioGX, the Netherlands). Bacteria DNA was studied with polymerase chain reaction for Neisseria meningitidis, Streptococcus pneumoniae and Haemophilus influenzae in the cerebrospinal fluid (CSF). M. pneumoniae PCR test was not conducted on the CSF samples of the cases.

M. pneumoniae-associated aseptic meningitis was identified with elevated protein and pleocytosis in the cerebrospinal fluid and with the exclusion of other aseptic meningitis agents. Encephalitis was identified with encephalopathy ongoing for $\geq 24$ hours (changes in consciousness, lethargy, irritability or personality changes) and fever, seizure, focal neurologic findings, presence of pleocytosis in CSF, electroencephalography suggestive of encephalitis and two or more imaging findings. Acute disseminated encephalomyelitis (ADEM) was identified as regards clinical and neurological examinations, cranial imaging characteristic on admission and control and CSF findings; Guillain Barre Syndrome (GBS) was identified according to clinic and neurologic examinations, albino-cytologic dissociation in CSF, myastenia gravis, typical clinical history, examination, typical pyridostigmine bromur response and EMG findings, cerebellitis was identified according to clinical, examination for AchR antibody positivity, and radiological imaging findings. In the differential diagnosis of ADEM, negativity was shown sending neuromyelitis optica antibody in serum. Since autoimmune encephalitis was present in the differential diagnosis of case 5, autoimmune panel was also demonstrated for this case. Postinfectious cerebellar ataxia was determined according to history, the nature of cerebellar ataxia, clinical findings of the patient, CSF findings and the characteristics of symptom-relief period.

\section{Results}

Prolonged cough was found in thirty, pneumonia in 52, parapneumonic effusion in 8 , arthritis in three, hemolytic anemia in 2 and neurologic involvement in 12 patients out of 107 in whom serum M. pneumoniae IgM positivity was detected,. Three patients were excluded from the study due to previous neurologic disorders. There were four females and five males in cases with neurologic involvement, whose ages ranged between 3 and 12. Four cases received aseptic meningitis, one received meningoencephalitis, one received ADEM, one received cerebellitis, one received postinfectious cerebellar ataxia, and one received MG diagnoses.

\section{Cases 1, 2, 3 and 4}

Four patients presented with fever, vomiting and headache. Physical examination revealed neck rigidity and Kernig and Brudzinski findings. Respiratory tract symptoms and pneumonia were found only in one of the patients. CSF white cell count more than $100 / \mathrm{mm}^{3}$ (counted by Thoma slide) and high protein were seen and CSF glucose was found normal as regards simultaneous blood glucose. The patients were admitted to the pediatric infectious diseases service with a diagnosis of aseptic meningitis. Herpes simplex 1 and 2, enterovi- 
rus, parechovirus, Western Nile virus, Listeria monocytogenes, Borrelia burgdorferi, pneumococcus, meningococcus, and $\mathrm{H}$. influenzae B from CSF were performed by RT-PCR. Ceftriaxone, acyclovir and clarithromycin treatment was initiated for the patients. Acyclovir treatment was terminated when CSF HSVtype 1 and 2 were resulted negative and ceftriaxone treatment was stopped when no growth was observed in CSF culture. M. pneumonia IgM was detected in acute serum sample [of the patients respectively; 1.18 Index, 1.27 Index,1.2 Index, 1.7 Index ( $<0.9$ negative)], and $a \geq 4$ increase was confirmed in IgG titer in the convalescence serum sample. M. pneumoniae PCR positivity was determined in the respiratory tract swab sample. Clarithromycin treatment was completed in 14 days. Additional problems were not seen in clinical follow-up of the patients.

\section{Case 5}

A 12-year-old male patient presented with complaints as fever, headache, vomiting and falling onto the ground. The patient had a seizure in the form of trance for 2-3 minutes during his follow-up in the pediatric emergency service. In the CSF examination of the patient, $240 / \mathrm{mm}^{3}$ white blood cell counted by Thoma slide and lymphocyte dominance in Giemsa staining were observed. CSF protein was $46 \mathrm{mg} /$ $\mathrm{dL}$ and glucose was $64 \mathrm{mg} / \mathrm{dL}$ (simultaneous blood glucose was $92 \mathrm{mg} / \mathrm{dL}$ ). HSV 1 ve 2, enterovirus, parechovirus, Western Nile virus, L. monocytogenes, B. burgdorferi, pneumococcus, meningococcus, $H$. influenzae B PCR were sent from the CSF and $M$. pneumoniae $\operatorname{lgM}$ ve $\lg G$ were sent from serum. The patient was admitted to the pediatric infectious diseases service with the diagnosis of meningoencephalitis. The patient was administered ceftriaxone, acyclovir, and clarithromycin treatment. In contrast-enhanced cranial magnetic resonance imaging (MRI), mild hypo-intensity in T1A on bilateral lentiform nuclei and hyperintense symmetrical lesions in T2 and FLAIR sequence were detected. It was reported in sections taken after intravenous contrast material injection that contrast staining was observed in cerebral sulcus and was concordant with leptomeningitis. During service follow-up, maintenance treatment was proceeded in the patient with generalized tonic colonic seizures. Midazolam infusion and phenytoin were started in the patient whose seizures continued. $1 \mathrm{~g} / \mathrm{kg}$ intravenous immunoglobulin (IVIG) treatment was administered. AMPA 1, 2, ANTI CASPR2, ANTI LGI, ANTI GABA from CSF and blood and autoimmune encephalitis panel were resulted negative. M. pneumoniae IgM (1.23 Index) and Ig G ( 2.1 Index) positivity was confirmed in acute serum sample. M. pneumoniae serology was not sent in convalescence serum due to the IVIG treatment received by the patient. The patient, whose ceftriaxone and acyclovir treatments were terminated, continued clarithromycin treatment for 14 days. When previous MRI was compared with control MRI taken three months later, it was seen that the increase in signal intensity observed on bilateral lentiform nuclei disappeared. M. pneumoniae IgM was found negative and IgG titer was increased. The patient who does not have an additional problem in polyclinic follow-ups maintains levetiracetam and phenytoin treatment.

\section{Case 6}

An 8-year-old female patient presented with headache, fever, nasal flow and obstruction, malaise, and derangement ongoing for the last two weeks. Neurological examination revealed that the patient had dysmetria and was unable to step consecutively on a single line. In CSF examination, 70/ $\mathrm{mm}^{3}$ white blood cell counted by Thoma slide (lymphocyte dominance in Giemsa staining), glucose $65 \mathrm{mg} / \mathrm{dL}$ (simultaneous blood glucose $90 \mathrm{mg} / \mathrm{dL}$ ), protein $34 \mathrm{mg} / \mathrm{dL}$. Ceftriaxone, acyclovir, and clarithromycin treatment was started for the patient. Cranial MRI showed in FLAIR sequence on the right cerebellar hemisphere an irregularly-margined hyperintense lesion with $3.5 \mathrm{~cm}$ anteroposterior diameter consistent with cerebellitis (Figure 1A). Steroid treatment was started. HSV 1 and 2, VZV, enterovirus, parechovirus, Western Nile virus, $L$. monocytogenes, B. burgdorferi, pneumococcus, meningococcus, $H$. influenzae B PCR sent from the CSF resulted negative. There was no growth in CSF culture. Acyclovir and ceftriaxone treatment were terminated. M. pneumoniae IgM (1.84 Index) positivity in acute serum sample and $\mathrm{a} \geq 4$-fold increase in lgG in convalescence serum sample were determined. Clarithromycin treatment was completed to fourteen days. Neurological examination of the patient on month 3 was normal, and it was seen in cranial MRI that the lesion on the right cerebellar hemisphere disappeared (Figure 1B).

\section{Case 7}

A 6-year-old male patient was brought to our hospital with complaints like dizziness, diplopia and unsteady gait that had started three-four hours prior to presentation. It was found out that the patient complained about fever, nasal obstruction, and dry cough two weeks prior. Neurological examination demonstrated that the patient walked wide-based, stumbled without support and could not sit without any support. Dysarthria was present. Deep tendon reflexes were bilateral $(+++)$ and the patient had dysmetria and dysdiadochokinesia. In FLAIR sections in cranial MRI, signal increase was seen in right temporal lobe insular cortex, right thalamus, and in pons tegmentum (Figure 1C). While CSF protein was $(65 \mathrm{mg} /$ $\mathrm{dL}$ ) and glucose was normal, there were 10 white blood cells/ $\mathrm{mm}^{3}$ in Thoma slide. HSV1 and 2, VZV, enterovirus, parechovirus, Western Nile virus, L. monocytogenes, B. burgdorferi, pneumococcus, meningococcus, $H$. influenzae B PCR sent from the CSF resulted negative. ADEM with brain stem involvement 


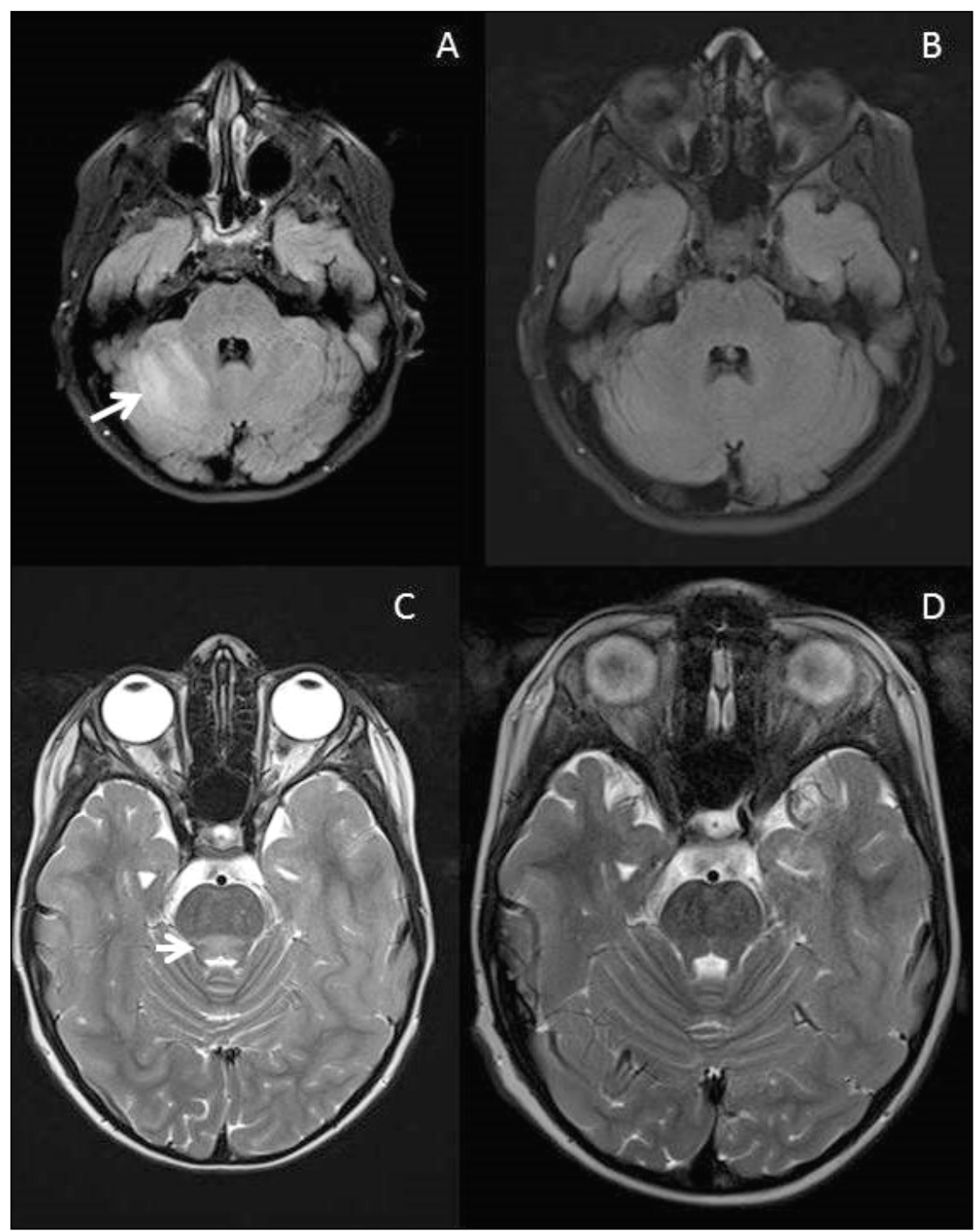

Figure 1. (A) Hyperintense lesion with irregular margins and a $3.5 \mathrm{~cm}$ anteroposterior diameter on the left cerebellar hemisphere on axial FLAIR sequence of cranial MRI of case number 6 (white arrow). (B) Shows that the present lesion has started to disappear on control MRI taken three months later. (C) Shows T2 signal increase seen on the pons tegmentum zone on axial FLAIR sequence in cranial MRI imaging of case number 7 (White arrow), and (D) demonstrates that the $\mathrm{T} 2$ signal increase disappeared on the control imaging performed 2 months later.

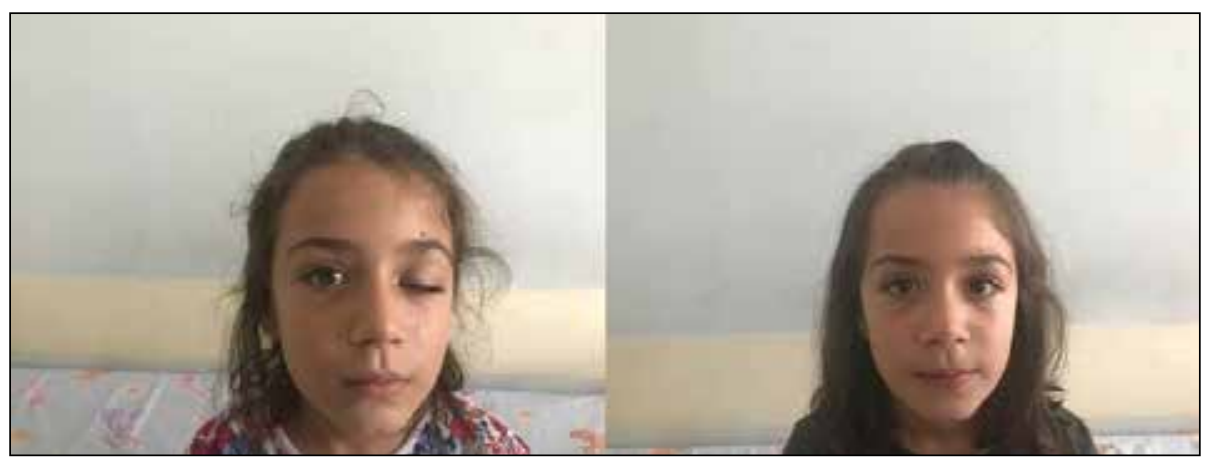

Figure 2. Ptosis appearance of case 9 on the left eye pre and post-pyridostigmine. 
was considered in clinical, laboratory and radiological imaging. Ceftriaxone, acyclovir, clarithromycin, IVIG and pulse methylprednisolone treatment were administered. Positivity in M. pneumoniae IgM (1.64 Index) and IgG (2.4) was detected in acute serum sample. M. pneumoniae serology was not sent in convalescence serum due to the IVIG treatment received by the patient. Clarithromycin treatment lasted 14 days and terminated. While the neurological examination of the patient conducted 1 week later was normal, it was seen in the radiological imaging performed one month later that everything was normal apart from the subtle T2 signal increase on pons. Serum M. pneumoniae IgM was negative and IgG titer was increased.

\section{Case 8}

A 2-year-old male patient presented with fever and upper respiratory tract infection ongoing for a week and newly onset of unsteady walking. Neurological examination demonstrated ataxia and that the patient sat with support and could stand on his feet for more than 10 seconds with interval support and was unable to walk on a single line position. The patient did not have apparent speech impediment and tremor in finger-nose follow. CSF findings of the patient were normal. Craniospinal MRI was also normal. The patient was admitted to the pediatric infectious diseases service with cerebellar ataxia diagnosis. Ceftriaxone and clarithromycin treatment were started. Positivity in M. pneumoniae IgM (2.6 Index) in acute serum sample and $\geq 4$-fold rise in $\lg G$ in convalescence serum sample were found. Respiratory tract swab sample confirmed M. pneumoniae $\mathrm{PCR}$ positivity. Ceftriaxone treatment was stopped when no growth was detected in CSF culture. Clarithromycin treatment lasted 14 days. Neurological examination of the patient performed ten days later was normal and there was no additional problem on polyclinic follow-ups.

\section{Case 9}

A 6-year-old female patient complaining about fever, nasal flow and obstruction, fatigue and malaise ongoing for four days was brought to the polyclinic with sudden onset of left eyelid ptosis one day prior. The patient indicated that there was no difference as regards daytime and nighttime. Neurologic examination revealed eyelid ptosis that covered $75 \%$ of the left eye of the patient. Bilateral eye movements were free in all directions. Other neurological examination findings were normal. Positivity in M. pneumoniae lgM (2.2 Index) in acute serum sample and $\geq 4$-fold rise in $\mathrm{Ig} G$ in convalescence serum sample were found. Respiratory tract swab sample confirmed M. pneumoniae PCR positivity. Clarithromycin treatment was started. Although signs of upper respiratory tract infection completely ameliorated, there was no remission in the left eyelid ptosis. The patient could not be cooperative to single fiber electromyelography. The patient was administered pyridostigmine bromide with oral dose of $3 \times 60 \mathrm{mg}$. Ptosis was seen to ameliorate significantly after 48 hours (Figure 2). Pyridostigmine treatment was continued. Acetylcholine receptor antibody was detected positive.

\section{Discussion}

M. pneumoniae is an important pathogen leading to neurological disorders during the course of or after respiratory tract infection. In $11.5 \%$ of the patients admitted to hospital for M. pneumoniae infection, M. pneumoniae-associated neurological complications are seen (4). Extrapulmonary diseases of $M$. pneumoniae are encountered more in children than in adults (1). Pathogenesis resulting in neurological disorders is still unknown. Pathogenesis has been attempted to be explained with three different mechanisms in studies conducted. First is the direct invasion of M. pneumoniae to the central nervous system, second is the indirect autoimmune mechanisms and third is the vascular type mechanisms explaining neurological involvement pathogenesis where vasculitis or thrombotic vascular occlusions take place with direct or indirect mechanism (5).

Encephalitis is the most commonly observed extrapulmonary neurological disease caused by M. pneumoniae (510\%) (6). Studies have shown that there are respiratory tract symptoms in two thirds of encephalitis cases associated with M. pneumoniae. Therefore, M. pneumoniae infection should be considered in encephalitis cases without respiratory tract symptoms and findings. In children clinically regarded as aseptic meningitis, there are cases that do not receive final diagnosis since $M$. pneumoniae test is not routinely performed and it is a self-limiting benign condition. Accordingly, M. pneumoniae meningitis is considered to be rarely seen (4). Neurologic diseases that develop due to direct invasion of M. pneumoniae occur within the first 7 days (6). M. pneumoniae has been shown with PCR in the CSF of the children with encephalitis and meningitis, which explains the fact that $M$. pneumoniae results in meningitis and encephalitis due to direct invasion. However, there are encephalitis and meningitis cases serologically diagnosed in the literature in whom $M$. pneumoniae could not be detected in the CSF (7-9). Some studies have put forth that $M$. pneumoniae encephalitis develop as a result of both direct and autoimmune mechanisms. M. pneumoniae DNA has been detected in the CSF in only two of the $111 \mathrm{M}$. pneumoniae encephalitis cases (10). The fact that DNA could not be detected and there is a latent period after respiratory symptoms suggest that there could be autoimmune mechanisms in encephalitis pathogenesis $(1,11)$. Laboratory verification of respiratory tract $M$. pneumoniae infection is troublesome in some encephalitis cases. Culture is complicated and slow. Serologic tests performed in acute and convalescence phases 
are considered gold standards. This condition brings about limitations to the acute phase diagnosis since retrospective diagnosis can been made. It is recommended that molecular tests detecting M. pneumoniae DNA be used together with acute phase serology (12). In the first four cases presented in this study, M. pneumoniae infection was shown serologically in serum and with PCR in respiratory tract swab samples, and it was considered that M. pneumoniae caused meningitis as a result of direct invasion by excluding all other agents.

Indirectly effective autoimmune mechanisms have been held responsible for the pathogenesis of $M$. pneumoniae-associated cerebellitis, cranial and peripheral neuropathy, ADEM, and TM. ADEM is a monophasic demyelinating immune-mediated disease seen generally in children. In a study evaluating 365 children in whom M. pneumoniae has been detected by PCR method in the CSF or respiratory tract swab sample, 42 of whom have been diagnosed with neurological diseases associated with M. pneumoniae. The $52 \%$ of these patients had encephalitis, 12\% had ADEM, 12\% had TM and 10\% had cerebellitis (4). It has been reported that patients with ADEM had respiratory tract complaints $>7$ days prior (4). Again in the literature, $M$. pneumoniae-associated ADEM cases have been identified. In the diagnoses of these patients, M. pneumoniae antibodies have been shown in serum with serologic tests. Since DNA cannot be detected with $M$. pneumoniae PCR in the CSF and respiratory tract in many patients and there is a certain amount of time between respiratory tract symptoms and neurologic symptoms, autoimmune mechanism is blamed in pathogenesis (13). However, the fact that $M$. pneumoniae DNA has been confirmed in the CSF of a patient diagnosed with M. pneumoniae-associated ADEM and that $M$. pneumoniae DNA has been determined in the brain biopsy material of a five-year-old child diagnosed with ADEM show that its pathogenesis has not still been fully explained $(14,15)$. Indirect mechanism can explain the fact that ADEM-diagnosed Case 7 had respiratory tract symptoms 7 days prior and M. pneumoniae infection diagnosis was serologically made. Along with the fact that latent period was present in one of the patients with cerebellitis diagnosis, latent period was not present in the other case and M. pneumoniae DNA was detected with PCR method in respiratory tract sample in addition to serologic response. It is seen that direct invasion and/or autoimmune indirect mechanism may have led to cerebellitis.

M. pneumoniae-associated MG cases have been reported rather scarcely in the literature. There is not sufficient information explaining the relation between $M$. pneumoniae infection and MG. As a cause and effect relation, the antigenic structure of the infectious agent and molecular similarity of the acetylcholine receptor has been predicted. It has been reported from our country that the onset of the disease of a child patient with MG was triggered with M. pneumoniae infection
(2). In an epidemiological study conducted in Japan in recent years, it has been indicated that Anti - Ach receptor antibody levels are quantitatively associated with M. pneumoniae and influenza virus. It has been put forth in the study that when other infectious agents were compared with environmental agents that trigger the formation of the disease, the effect of particularly M. pneumoniae and influenza was more significant (16). In the patient presented, evidencing M. pneumoniae infection with serologic and molecular tests together with the presence of respiratory tract symptoms suggested $M$. pneumoniae infection to be the reason of MG.

The treatment of $M$. pneumoniae-associated neurologic diseases is controversial. The administration of systemic antibiotic treatment independent of the type of the disease and its pathogenesis is recommended in most studies. Particularly in early-onset cases that form directly-effective CNS damage in pathogenesis, antibiotic treatment is required in the protection of the cytolytic activity of the microorganism and in preventing the activation of the immune system by producing cytokine and chemokine. In cases with late-onset autoimmune mechanism at play, the eradication of M. pneumoniae from the respiratory tract may suspend autoimmunity and related events that could develop (1). Therefore, antibiotic treatment is needed in these patients. All of the patients were administered systemic clarithromycin. Moreover, macrolides are strong immunomodulator drugs and can increase or decrease the activation of the immune system by regulating the synthesis and/or secretion of proinflammatory and anti-inflammatory cytokines (17). Diseases characterized with suspected or proven acute severe inflammation are treated with steroids and/or IVIG. Plasma change can be carried out in refractory cases. In patients in whom plasma change is ineffective, immunosuppressive and biologic agents can be used. Since pathogenesis is not fully known, the treatment of M. pneumoniae-associated neurologic diseases is also not fully known. In studies conducted, there have been patients that benefited from IVIG, steroid and/or plasmaphereses and authors have supported the use of these treatments (4). In addition to the antibiotic treatment, patients with encephalitis, cerebellitis and ADEM, had been administrated to IVIG and steroid treatment. Brain, brain stem and cerebellum involvement and rapid amelioration of the patients with IVIG and steroid treatment suggest that there is an autoimmune mechanism in pathogenesis.

In conclusion, even though M. pneumoniae is known as the main respiratory tract pathogen, it also causes various neurological diseases. It has been shown that it may lead to neurological diseases where there are no respiratory tract symptoms. Therefore, M. pneumoniae should be investigated as an agent in patients with neurological involvement with or without respiratory system tract symptoms and findings. 
Ethics Committe Approval: Ethics committee approval was not received due to the retrospective nature of this study.

Informed Consent: Written informed consent was not received due to the retrospective nature of this study. The required consents was obtained from the presented cases and their families.

Peer-review: Externally peer-reviewed.

Author Contributions: Concept - ZGGA; Design - ZGGA, EAA; Supervision - ZGGA, EAA; Funding - ZGGA, EAA; Materials - ZGGA, $E A A ;$ Data Collection and/or Processing - ZGGA; Analysis and/or Interpretation - ZGGA, EAA; Literature Review - ZGGA, EAA; Writing ZGGA, EAA; Critical Review - ZGGA, EA.

Conflict of Interest: No conflict of interest was declared by the authors.

Financial Disclosure: The authors declared that this study has received no financial support.

\section{References}

1. D'Alonzo R, Mencaroni E, Di Genova L, Laino D, Principi N, Esposito S. Pathogenesis and treatment of neurologic diseases associated with mycoplasma pneumoniae infection. Front Microbiol 2018;9:2751.

2. Yiş U, KurulSH, Cakmakçi H, Dirik E. Mycoplasma pneumoniae: nervous system complications in childhood and review of the literature. Eur $J$ Pediatr 2008;167:973-8.

3. Koskiniemi M. CNS manifestations associated with Mycoplasma pneumoniae infections: summary of cases at the University of Helsinki and review. Clin Infect Dis 1993;17:52-7.

4. Al-Zaidy SA, MacGregor D, Mahant S, Richardson SE, Bitnun A. Neurological Complications of PCR-Proven M. pneumoniae Infections in Children: Prodromal IIIness Duration May Reflect Pathogenetic Mechanism. Clin Infect Dis 2015;61:1092-8.

5. Narita M. Pathogenesis of extrapulmonary manifestations of Mycoplasma pneumoniae infection with special reference to pneumonia. $J$ Infect Chemother 2010;16;162-9.
6. Meyer Sauteur PM, Streuli JC, Iff T, Goetschel P. Mycoplasma pneumoniae-associated encephalitis in childhood--nervous system disorder during or after a respiratory tract infection. Klin Padiatr 2011;223:209-13.

7. Abele-Horn M, Franck W, Busch U, Nitschko H, Roos R, Heesemann J. Transverse myelitis associated with Mycoplasma pneumoniae infection. Clin Infect Dis 1998;26:909-12.

8. Narita M, Itakura O, Matsuzono Y, Togashi T. Analysis of mycoplasmal central nervous system involvement by polymerase chain reaction. Pediatr Infect Dis J 1995; 14:236-7.

9. Narita M, Matsuzono $Y$, Togashi T, Kajii N. DNA diagnosis of central nervous system infection by Mycoplasma pneumoniae. Pediatrics 1992;90;250-3.

10. Christie LJ, Honarmand S, Talkington DF, Gavali SS, Preas $C$, Pan $C Y$, et al. Pediatric encephalitis: what is the role of Mycoplasma pneumoniae? Pediatrics 2007;120;305-13.

11. Daxboeck F, Blacky A, Seidl R, Krause R, Assadian O. Diagnosis, treatment, and prognosis of Mycoplasma pneumoniae childhood encephalitis: systematic review of 58 cases. J Child Neurol 2004;19:865-71.

12. Qu J, Gu L, Wu J, Dong J, Pu Z, Gao Y, et al. Accuracy of IgM antibody testing, FQ-PCR and culture in laboratory diagnosis of acute infection by Mycoplasma pneumoniae in adults and adolescents with communityacquired pneumonia. BMC Infect Dis 2013;13:172.

13. Schmucker RD, Ehret A, Marshall GS. Cerebellitis and acute obstructive hydrocephalus associated with Mycoplasma pneumoniae infection. Pediatr Infect Dis J 2014;33;529-32.

14. Matsumoto N, Takahashi S, Toriumi N, Sarashina T, Makita Y, Tachibana $Y$, et al. Acute disseminated encephalomyelitis in an infant with incontinentia pigmenti. Brain Dev 2009;31;625-8.

15. Cadario ME, Ellis A, Garea M, Cairnie A, Mistchenko A, García Roig C, et al. Acute disseminated encephalomyelitis due to Mycoplasma pneumoniae in a previously healthy boy. Rev Argent Microbiol 2018.

16. Iwasa K, Yoshikawa H, Hamaguchi T, Sakai K, Shinohara-Noguchi M, Samuraki M. Time-series analysis: variation of anti-acetylcholine receptor antibody titer in myasthenia gravis is related to incidence of Mycoplasma pneumoniae and influenza virus infections. Neurol Res 2018;40:102-9.

17. Kwiatkowska B, Ma'sli'nska M. Macrolide therapy in chronic inflammatory diseases. Mediators Inflamm 2012:636157. 